\title{
PENDAMPINGAN HUKUM UNTUK MENINGKATKAN KETERAMPILAN MASYARAKAT DALAM PEMBUATAN PERJANJIAN UNTUK MENUNJANG KEGIATAN USAHA DI DESA GEMPOL DAN RANCADAKA KECAMATAN PUSAKANAGARA KABUPATEN SUBANG
}

\author{
Zamil, Y.S., Faisal, P., dan Suwandono, A. \\ Fakultas Hukum Universitas Padjadjaran \\ E-mail: yusuf_zamil@yahoo.com
}

\begin{abstract}
ABSTRAK
Berdasarkan hasil survey ke lapangan, sebagian besar mata pencaharian masyarakat Desa Gempol dan Rancadaka Kecamatan Pusakanagara Kabupaten Subang adalah sebagai petani sawah dan petani penghasil buah-buahan terutama buah mangga. Desa Rancadaka bahkan sebagai salah satu desa penghasil padi terbesar di Kabupaten Subang, sedangkan desa Gempol merupakan desa dengan penghasil buah mangga terbesar di Kabupaten Subang. Oleh karena potensi pertanian yang cukup besar tersebut harus ditopang dengan keahlian masyarakat dalam membuat perjanjian tertulis agar lebih menjamin kepastian hukum usaha masyarakat yang tujuan akhirnya dapat meningkatkan kesejahteraan masyarakat.

Pendampingan Hukum Untuk Meningkatkan Keterampilan Masyarakat Dalam Pembuatan Perjanjian Untuk Menunjang Kegiatan Usaha Di Desa Gempol Dan Rancadaka Kecamatan Pusakanagara Kabupaten Subang dilakukan pada Hari Kamis Tanggal 03 Juli 2014 di Sekolah Dasar Negeri Desa Gempol. Pendampingan hukum dihadiri oleh sekitar 50 (lima puluh) orang, pendampingan hukum ini sangat penting dilakukan untuk memberikan keterampilan kepada masyarakat bagaimana caranya membuat perjanjian tertulis.

Pada saat dilakukan pendampingan hukum, hampir sebagian besar masyarakat Desa Gempol dan Rancadaka, Kecamatan Pusakanagara, Kabupaten Subang tidak menggunakan perjanjian tertulis dalam melakukan transaksi jual beli, sewa menyewa dan transaksi-transaksi lainnya. Setelah dilakukan pendampingan hukum masyarakat menjadi sadar akan pentinganya menggunakan perjanjian tertulis untuk memberikan kepastian hukum terhadap aktivitas usahanya. Setelah dilakukan pendampingan hukum masyarakat Desa Gempol dan Rancadaka Kecamatan Pusakanagara, Kabupaten Subang menjadi terampil dan sekurang-kurangnya mempunyai gambaran bagaimana membuat perjanjian tertulis, karena dalam pendampingan hukum diberikan pelatihan langsung bagaimana praktek dan tahapan dalam pembuatan perjanjian tertulis mulai dari kepala perjanjian, para pihak dalam perjanjian, maksud dan tujuan dibuatnya perjanjian, sampai kepada pasal-pasal yang harus ada dalam perjanjian dan penutup dari suatu perjanjian.
\end{abstract}

Kata Kunci: Pendampingan, Hukum, Perjanjian, Tertulis

\section{ABSTRACT}

Based on the survey results to the field, most of the people's livelihood Gempol village and sub-district Rancadaka Pusakanagara Subang Regency is as rice farmers and farmers producing fruits especially mangoes. Rancadaka village even as one of the largest rice-producing village in the district of Subang, while Gempol village is the village with the largest producer of mangoes in Subang. Therefore, a sizeable agricultural potential should be supported by the expertise of society in a written agreement in order to ensure legal certainty the business community that the goal can ultimately improve the welfare of the community.

Legal Assistance Society For Improving Skills In Development Agreements to Support Business Activity In the village Gempol And Rancadaka Pusakanagara District of Subang made on Thursday July 3, 2014 Date of State Elementary School in the village of Gempol. Legal assistance was attended by approximately 50 (fifty) people, legal assistance is very important to provide skills to the public how to make a written agreement.

At the time of legal assistance, most of the villagers Gempol and Rancadaka, District Pusakanagara Subang district does not use written agreements to make buying and selling, leasing and other transactions. After legal assistance pentinganya society becomes aware of the use of a written agreement to provide legal certainty for its business activities. After legal assistance villagers Gempol and Rancadaka District of Pusakanagara, Subang become skilled and at least have an idea of how to make a written agreement, since the legal assistance given direct training how to practice and stages in the manufacture of a written agreement from the heads of agreement, the parties in agreement, the intent and purpose of the treaty, to the clauses which must exist in the agreement and the closing of an agreement.

Keywords: Assistance, Legal, Agreements, Written

\section{PENDAHULUAN}

Desa Gempoldan RancadakaKecamatanPusakanagara Kabupaten Subang memiliki potensi unggulan, lahan pertanian padi, tanaman pangan/holtikultura, peternakan sapi dan domba, lahan perikanan dan tempat penjualan/ pemasaran, pariwisata alam dan lain-lain. Tempatnya yang terletak di kawasan Pantura menyebabkan Desa Gempol dan Rancadaka merupakan daerah yang sangat strategis untuk pemasaran dan jalur distribusi hasil-hasil perdagangan dan pertanian karena dekat dengan jalur lalu lintas dari arah Jawa Timur dan Jawa Tengah menuju Jawa Barat dan Jakarta.

Pertumbuhan penduduk yang semakin meningkat menyebabkan kegiatan usaha perdagangan dan pertanian semakin meningkat pesat, hal ini sebagaimana juga dirasakan oleh masyarakat Desa Gempol dan Rancadaka Kecamatan Pusakanagara Kabupaten Subang. Pada umumnya masyarakat belum sepenuhnya menyadari pentingnya memiliki keterampilan dalam membuat perjanjian karena dengan membuat perjanjian yang baik akan menunjang kegiatan usaha masyarakat agar lebih memberikan kepastian hukum dan apabila suatu perjanjian tidak dibuat secara tertulis rentan terjadinya sengketa dikemudian hari.

Berdasarkan hasil survey ke lapangan, sebagian besar mata pencaharian masyarakat Desa Gempol dan Rancadaka Kecamatan Pusakanagara Kabupaten 
Subang adalah sebagai petani sawah dan petani penghasil buah-buahan terutama buah mangga. Desa Rancadaka bahkan sebagai salah satu desa penghasil padi terbesar di Kabupaten Subang, ${ }^{1}$ sedangkan desa Gempol merupakan desa dengan penghasil buah mangga terbesar di Kabupaten Subang. ${ }^{2}$ Oleh karena potensi pertanian yang cukup besar tersebut harus ditopang dengan keahlian masyarakat dalam membuat perjanjian agar lebih menjamin kepastian hukum usaha masyarakat yang tujuan akhirnya dapat meningkatkan kesejahteraan masyarakat.

Pendampingan Hukum Untuk Meningkatkan Keterampilan Masyarakat Dalam Pembuatan Perjanjian Untuk Menunjang Kegiatan Usaha Di Desa Gempol Dan Rancadaka Kecamatan Pusakanagara Kabupaten Subang dilakukan pada Hari Kamis Tanggal 03 Juli 2014 di Sekolah Dasar Negeri Desa Gempol. Pendampingan hukum dihadiri oleh sekitar 50 (lima puluh) orang, pendampingan hukum ini sangat penting dilakukan untuk memberikan keterampilan kepada masyarakat bagaimana caranya membuat perjanjian tertulis. Aktivitas ekonomi di Desa Gempol dan Desa Rancadaka sangat berkembang pesat, yang sebagian besar mata pencahariannya adalah sebagai petani beras dan buah mangga. Desa Gempol dan Desa Rancadaka dikenal sebagai penyuplay beras dan mangga ke pasarpasar Induk yang ada di Kabupaten Subang, Karawang, bahkan kepasar induk yang ada di Jakarta dan Bandung.

Dalam menunjang aktivitas perekonomian masyarakat tersebut tentunya harus dibekali oleh suatu keterampilan dalam membuat perjanjian tertulis yang akan sangat bermanfaat bahkan dapat meningkatkan kesejahteraan masyarakat di Desa Gempol dan Rancadaka, Kecamatan Pusakanagara, Kabupaten Subang. Dengan menggunakan perjanjian tertulis dalam aktivitas ekonomi masyarakat, seperti dalam perjanjian jual beli hasil pertanian, sewa menyewa lahan atau aktivitas perekonomian lainnya akan lebih memberikan kepastian hukum bagi petani yang menjual hasil buminya bahkan akan terhindar dari kerugian.

\section{SUMBER INSPIRASI}

Sumber inspirasi didasarkan pada kenyataannya bahwa masyarakat Desa Gempol dan Desa Rancadaka, Kecamatan Pusakanagara Kabupaten Subang, tidak menggunakan perjanjian tertulis dalam aktivitas sehari-harinya, seperti dalam jual beli hasil pernian maupun dalam sewa menyewa lahan pertanian. Hal ini akan sangat merugikan masyarakat karena tidak memberikan kepastian hukum dan rentan terjadinya sengketa dikemudian hari. Apalagi Desa Gempol dan Desa Rancadaka mempunyai potensi ekonomi yang sangat potensial sebagai salah satu penghasil padi dan buah mangga terbesar di Kabupaten Subang. Dengan menggunakan perjanjian tertulis akan memberikan kepastian hukum dan bahkan dapat meningkatkan penghasilan masyarakat

\footnotetext{
${ }^{1}$ Berdasarkan hasil wawancara dengan Bapak Ato Suryanto, Kepala Desa Rancadaka Kecamatan Pusakanegara, Kabupaten Subang, tanggal 26 Mei 2014.

${ }^{2}$ Berdasarkan hasil wawancara dengan Bapak Sanudi, Kepala Desa Gempol Kecamatan Pusakanegara, Kabupaten Subang, tanggal 26 Mei 2014.
}

\section{BAHAN DAN METODE}

Pendampingan hukum berlokasi di SDN Otista disamping Kantor Desa Gempol, Kecamatan Pusakanagara, Kabupaten Subang, yang dilaksanakan pada pada hari Kamis, tanggal 03 Juli 2014. Metode yang digunakan untuk mencapai tujuan yang telah dicanangkan adalah sebagai berikut:

1. Survey wilayah sebagai tempat mengadakan penyuluhan hukum.

2. Ceramah dan diskusi.

3. Praktek pembuatan perjanjian tertulis

\section{KARYA UTAMA}

Pemberian materi tidak hanya dilakukan dengan memberikan teori perjanjian tetapi dilakukan dengan memberikan contoh perjanjian sewa menyewa lahan perkebunan dan perjanjian jual beli yang sederhana dan mudah dipahami oleh masyarakat. Setiap unsur dalam perjanjian sewa menyewa lahan perkebunan dan perjanjian jual beli dibahas satu persatu oleh tim PKM mulai dari judul perjanjian, para pihak dalam perjanjian, kalimat dalam pasal-pasal perjanjian sewa menyewa lahan dan perjanjian jual beli. Dengan pembahasan yang sangat mendalam setiap unsur dalam perjanjian tersebut, diharapkan setelah dilakukan pendampingan hukum masyarakat dapat membuat perjanjian tertulis atau setidak-tidaknya ada gambaran bagaimana membuat perjanjian tertulis. Untuk itu tim PKM memberikan photo copy draf perjanjian sewa menyewa lahan dan perjanjian jual beli yang dapat dijadikan pedoman oleh masyarakat dalam membuat perjanjian tertulis.

\section{ULASAN KARYA}

Kegiatan ini merupakan Pendampingan Hukum Untuk Meningkatkan Keterampilan Masyarakat Dalam Pembuatan Perjanjian Untuk Menunjang Kegiatan Usaha Di Desa Gempol Dan Rancadaka Kecamatan Pusakanagara Kabupaten Subang. Peserta merupakan perwakilan dari Rukun Warga, Majelis Ulama Desa, tokoh masyarakat, aparat desa, masyarakat umum, dan mahasiswa peserta KKNM.

Masyarakatsangatantusiasmengikutipendampingan hukum, hal ini terlihat dari banyaknya pertanyaan yang ditanyakan oleh masyarakat. Pertanyaan-pertanyaan yang ditanyakan oleh masyarakat diantaranya adalah bagaimana dengan perjanjian gadai dengan kondisi pembeli gadai dalam hal ini pemberi pinjaman uang tidak dapat memetik hasil dari kolam ikan yang digadaikan oleh penjual gadai yang meminjam uang karena selalu gagal panen dan sudah lewat waktu tujuh tahun batas akhir pengembalian barang yang digadaikan. Tim PKM menjelaskan bahwa sudah menjadi resiko yang harus ditanggung oleh pembeli gadai kalau tidak dapat memetik hasil dari barang yang digadaikan karena gagal panen dan tidak dapat menuntut pengembalian uang gadai karena sudah lewat jangka waktu gadai selama tujuh tahun, hal ini sebagaimana diatur dalam Peraturan Menteri Pertanian No. 20 Tahun 1963 Tentang Pedoman Penyelesaian Masalah Gadai.

Kondisi tersebut sangat jarang terjadi karena kecil kemungkinan selama tujuh tahun pembeli gadai tidak 
dapat memunggut hasil dari kolam ikan yang digadaikan. Pada umumnya masyarakat tidak mengetahui aturan yang mewajibkan pembeli gadai mengembalikan barang yang digadaikan setelah tujuh tahun, sehingga praktek yang terjadi selama penjual gadai tidak dapat melunasi hutangnya, maka barang yang digadaikan masih tetap dalam penguasaan pembeli gadai jelas hal ini bertentangan sebagaimana yang diatur dalam Peraturan Menteri Pertanian No. 20 Tahun 1963 Tentang Pedoman Penyelesaian Masalah Gadai. tersebut. Oleh karena itu, untuk menghindari terjadinya sengketa dikemudian hari, maka perjanjian gadai harus dilakukan dengan perjanjian tertulis. Dengan perjanjian tertulis maka akan menghindari terjadinya sengketa atau perbedaan penafsiran karena para pihak dalam perjanjian harus tunduk kepada hal-hal yang diatur dalam perjanjian.

Masyarakat juga menanyakan fungsi materai dalam perjanjian, tim PKM menjelaskan bahwa materai dalam perjanjian bukan syarat sahnya perjanjian, sehingga para pihak yang tidak menggunakan materai, maka perjanjian tersebut masih tetap sah dan mengikat para pihak yang menandatangani perjanjian. Namun demikian sebaiknya para pihak mencantumkan materai dalam perjanjian, karena penggunaan materai dalam suatu perjanjian merupakan bukti bahwa para pihak dalam perjanjian telah membayar pajak. Akibatnya apabila para pihak tidak mencantumkan materai dalam perjanjian, maka perjanjian tersebut tidak dapat dijadikan alat bukti dalam persidangan. Untuk dapat dijadikan alat bukti dalam persidangan, maka perjanjian tersebut harus di naseglin (dicap) di kantor pos dengan membayar sejumlah uang tertentu untuk mengganti materai sebagai bukti telah bayar pajak.

Dalam kegiatan pendampingan hukum pembuatan perjanjian tertulis masyarakat sangat kritis, dengan menanyakan setiap redaksional kata-kata dan kalimatkalimat dalam perjanjian jual beli dan sewa menyewa lahan. Dalam Pendampingan hukum juga diberikan penjelasan mengenai tata cara pembuatan surat kuasa, karena dalam praktek dimasyarakat banyak perjanjian sewa menyewa lahan atau rumah, dimana pemilik lahan atau rumah memberikan kuasa kepada orang lain untuk menyewakan rumah atau lahan.

Berdasarkan hasil ceramah dan diskusi dengan peserta sebagai khayalak sasaran diketahui bahwa masyarakat tidak mengerti dan belum mempunyai kesadaran akan pentingnya perbuatan perjanjian tetulis. Namun demikian, setelah dilakukan pendampingan hukum masyarakat menjadi sadar akan pentinganya membuat perjanjian tertulis dalam menunjang aktivitas usaha masyarakat, bahkan setelah dilakukan pendampingan hukum masyarakat menjadi terampil membuat perjanjian tertulis.

\section{Dampak dan Manfaat Kegiatan}

Manfaat yang didapatkan dari Pendampingan Hukum Untuk Meningkatkan Keterampilan Masyarakat Dalam Pembuatan Perjanjian Untuk Menunjang Kegiatan Usaha Di Desa Gempol Dan Rancadaka Kecamatan Pusakanagara Kabupaten Subang adalah Masyarakat mempunyai keterampilan dalam membuat perjanjian tertulis dalam menunjang aktivitas perekonomiannya, Masyarakat dapat meningkatkan penghasilannya, Memberikan kepastian hukum bagi masyarakat dalam melakukan transaksi jual beli, sewa menyewa dan lain-lain.

\section{SIMPULAN}

Berdasarkan hasil survey ke lapangan sebelum dan pada saat dilakukan pendampingan hukum, hampir sebagian besar masyarakat Desa Gempol dan Rancadaka, Kecamatan Pusakanagara, Kabupaten Subang tidak menggunakan perjanjian tertulis dalam melakukan transaksi jual beli, sewa menyewa dan transaksitransaksi lainnya. Setelah dilakukan pendampingan hukum masyarakat menjadi sadar akan pentinganya menggunakan perjanjian tertulis untuk memberikan kepastian hukum terhadap aktivitas usahanya.

Setelah dilakukan pendampingan hukum masyarakat Desa Gempol dan Rancadaka Kecamatan Pusakanagara, Kabupaten Subang menjadi terampil dan sekurang-kurangnya mempunyai gambaran bagaimana membuat perjanjian tertulis, karena dalam pendampingan hukum diberikan pelatihan langsung bagaimana praktek dan tahapan dalam pembuatan perjanjian tertulis mulai dari kepala perjanjian, para pihak dalam perjanjian, maksud dan tujuan dibuatnya perjanjian, sampai kepada pasal-pasal yang harus ada dalam perjanjian dan penutup dari suatu perjanjian.

\section{DAFTAR PUSTAKA}

J. Satrio, Hukum Perikatan, Perikatan Pada Umumnya, Bandung: Alumni, 1999.

Kartini Muljadi \& Gunawan Widjaja, Perikatan Yang Lahir Dari Perjanjian, Jakarta: RajaGrafindo Persada, 2003.

Salim, Perkembangan Hukum Kontrak Innominat Di Indonesia, Jakarta: Sinar Grafika, 2008.

Soedjono Dirdjosisworo, Kontrak Bisnis (Menurut Sistem Civil Law, Common Law, dan Paktek Dagang Internasional, Bandung: Mandar Maju, 2003.

Kitab Undang-Undang Hukum Perdata

Undang-undang No. 2 Tahun 1960 tentang Perjanjian Bagi Hasil

Peraturan Menteri Pertanian No. 20 Tahun 1963 Tentang Pedoman Penyelesaian Masalah Gadai.

Berdasarkan hasil wawancara dengan Bapak Ato Suryanto, Kepala Desa Rancadaka Kecamatan Pusakanegara, Kabupaten Subang, tanggal 26 Mei 2014.

Berdasarkan hasil wawancara dengan Bapak Sanudi, Kepala Desa Gempol Kecamatan Pusakanegara, Kabupaten Subang, tanggal 26 Mei 2014. 